\title{
The study of the effect of the individual perception of justice (belief in a just world) on degree of decision- making of students of the faculty of physical education and sport sciences
}

\author{
Rezzan DEMIRCI, Gulsum YILMAZ, Buket KAYAOGLU, Gokhan ACAR \\ Faculty of Sport Sciences, Usak University, Turkey. \\ Address Correspondence to G. Acar, gokhnacar@gmail.com
}

\begin{abstract}
This study aims to reveal the research results of the effects of the relation between individual perception of justice (belief in a just world) and decision-making on the students of faculty of physical education and sport sciences. In this context, what is the degree of individual perception of just world of the students? What is the degree of the students' self-esteem? What are students' decision making styles? Does students' individual perception of justice, degree of self-esteem at decision-making and decision-making styles show difference in terms of their demographic features? Is there a significant relationship between students' individual perception of just world, and their self-esteem at decision-making and decision-making styles? These are the questions that are investigated. In order to determine between students' individual perception of a just world and decisionmaking styles, arithmetic mean and standard deviation values are examined. T test and one-way ANOVAs test are applied to determine whether students' individual perception of a just world and decision-making styles change according to their demographic features. The mean of the answers to the questions about students' individual perception of just world is calculated as 3.73. Students' individual perception of a just world is quite close to 4 (neutral value). According to this, it seems that students' individual perception of a just world is at the degree of indecision. The value of the mean of the first six items that the students' degree of self-esteem is determined is 2.52 which is the degree of accurate. According to that, we can say that students' degree of self-esteem at decision-making is high. The mean of the answers that the students gave to the questions about decision-making delay is 1.91 which is at the degree of sometimes accurate. According to that, we can say that students sometimes delay their decision-making process. When we compare students' individual perception of just world, and their self-esteem at decision-making and decision-making styles in terms of their demographic features, it is seen that there is not a significant difference between the groups according to variables of gender, the grade they are in, their department they study and the dwelling place. It is seen that there is a significant difference only according to the variables of degree of doing sports and the habitual residence.
\end{abstract}

Keywords: Decision-making, individual perception of Justice (belief in a just world), students, physical education.

\section{INTRODUCTION}

Individual Perception of Justice (Belief in a Just World)

According to the theory, people are tend to perceive that the world is a place where people get what they deserve; in return of their good acts, good things will happen while in return of their bad acts, bad things will happen. That is why; they believe that they deserve all the things that happen to them in the world (14). According to the belief in a just world theory, people are tend to believe that the unpleasant things that happened to the unfortunate victim are caused by the victim himself. This tendency is because of the need of staying away from chaos by regaining their self-control and legitimizing justice on the world in order to protect themselves from the negative effects of the events. Otherwise, as the events whose results cannot be predicted or happens unjustly out of their estimation can cause a lot of physical and psychological problems, it will increase the senses as powerlessness, desperation and helplessness (17). According to Lipkus (19), people are tend to believe that there is a matching between the action that happens to them and performed action. Along with individuals' beliefs that they can get what they want by performing certain actions and can avoid unpleasant situations, it also increases the ability to control environment, doing long term plans and 
process of adaptation. It constitutes one of the responsibility attribution mechanisms that they use to explain positive or negative events that people experienced or observed. It is asserted that belief in a just world is a hidden belief and so individuals are not aware of neither its effect nor its existence $(12,18)$. Belief in a just world changes according to a person's features and behaviors (23). In sum, it can be said that the belief in a just world has three main functions. 1- Individual acts as if he signed a personal contract on obligation to act justly. 2- It provides a conceptual system that helps to reinterpret the events in the individual's personal life in a meaningful way and as a result; 3- it guarantees that they will be justly treated by others and when an unexpected disaster occurs, they will not be victims. These features of the belief in a just world explain a great part of the human behavior and it has vital importance for individual to invest in future (22).

\section{Decision Making}

Decision making is one of the most important survival skills. The decisions made in appropriate way, at the right time causes positive changes individual's life while the decisions made in a wrong way can affect the life negatively (11). According to Bağırkan (2), decision-making is to determine the option which will give the best result by evaluating one or more problems which have to be ended in terms of its all dimensions. Decisionmaking is the whole of the cognitive and behavioral efforts about choosing and making preferences among a variety of situations (16). Decision-making is unique to people who has wisdom, thought, conscious and will state that individuals have responsibilities for decision-making $(15,16)$. Decision-making is both managerial and organizational process. Decision-making is managerial because it is the basic responsibility of the manager. On the other hand, decision-making is an organizational process because every last decision is the product of the efforts of many workers from different levels in the organization. Decision-making is a process which is product of a group, even a computer. That is why; a decision constructs the focus of both managerial and organizational action (5). The theoretical frame that decision-making is basically based on Social-leaning Theory, Pragmatism Theory, Cognitive Motivation Theory and Dissonance Theory $(7,20,21)$.

\section{MATERIAL \& METHOD}

In the study, correlation and causal comparative techniques are used. Correlation research is to examine the relationship between two things without putting effort to affect the variables. Causal comparative technique aims to find possible reasons to a set of behaviors by comparing two groups who have these set of behaviors and do not. There are at least two variables in designating relationship with comparative technique. According to independent variable, groups are formed and whether a difference among them has occurred or not according to dependent variable is examined (3).

\section{Data Analysis}

The target population of this study was Erciyes University students of faculty of physical education and sport sciences in the fall term of 2014-2015. Individuals were selected by using non-probability convenience sampling approach. The grades of the students are 1, 2, 3 and fourth year students. The sample of the target group consists of 87 students from department of physical education and sports, 64 students from training college, 5 students from department of recreation, and 12 students from the department of sports management, in total 168 students (65 female and 103 male students).

The collected data were analyzed and evaluated by using SPSS 13.0. Frequency analysis is done to describe student's demographic information who participated in the study. Arithmetic mean and standard deviation values are examined to determine student's individual perception of a just world and decision-making styles. T test and one-way ANOVAs test are applied to determine whether students' individual perception of a just world and decision-making styles change according to their demographic features. In the questionnaire which is used to determine student's individual perception of a just world, a 7 graded scale is used and value 1 means it is quite incorrect (strongly disagree) while value 4 means neutral and value 7 means quite correct (strongly agree). To determine whether there is significant relationship between student's individual perception of a just world and decisionmaking styles, correlation coefficient is taken as base.

Pearson correlation coefficient is interpreted as “ $\mathrm{R} 0.00$ - 0.25 extremely weak relation, $\mathrm{R} 0.26-0.49$ weak relation, $\mathrm{R} 0.50-0.69$ average relation, $\mathrm{R} 0.70-$ 0.89 high relation, R $0.90-1.00$ extremely high relation". 


\section{Data Collection Tools}

As data collection tool, individual belief in a just world scale (KADİÖ) is chosen. The scale which is developed by (8) and adapted to Turkish and validity and reliability is tested by (13). The other scale which is chosen is Melbourne Decision-making Questionary. This scale is originally developed by (20), (9) adapted Melbourne Decision Making Questionary to Turkish, and tested its validity and reliability.

\section{RESULTS}

When the table 1 is examined, the mean of the answers to the questions about students' individual perception of just world is calculated as 3.73. Students' individual perception of a just world is quite close to 4 (neutral value). According to this, it seems that students' individual perception of a just world is at the degree of indecision.

If we examine the figure, we see that the value of the mean of the first six items that the students' degree of self-esteem is determined is 2.52 which is the degree of accurate. According to that, we can say that students' degree of self-esteem at decisionmaking is high.

When the table 3 is examined, it seen that students' perception of a just world, careful decision-making, evasive decision-making, decisionmaking delay and panic decision-making styles do not change according to their level of doing $\operatorname{sports}(\mathrm{p}>0.05)$. It is seen that there is a significant difference at the self-esteem at decision-making factor according to students' level of decisionmaking $(\mathrm{p}<0.05)$.

When the table 4 is examined, it is seen that there is a significant difference between students who do sports as a leisure time activity and as professionals and students at the national level. According to that, mean of self-esteem at decision making of the students at the national level is significantly higher than students who do sports as a leisure time activity and as professionals.

Table 1. Mean and Standard deviation values of students' individual perception of a just world.

\begin{tabular}{|c|c|c|c|}
\hline & $\mathrm{N}$ & Mean & SD \\
\hline 1. No matter what you say, some groups are more important. & 168 & 3.43 & 1.73 \\
\hline 2. Equal chance should be given to each group. & 168 & 4.54 & 1.62 \\
\hline 3. Superior groups should dominate inferior groups. & 168 & 2.64 & 1.75 \\
\hline 4. None of the groups should be dominant in the society. & 168 & 4.02 & 1.61 \\
\hline 5. If certain groups had stayed still, we would have fewer problems. & 168 & 3.84 & 1.66 \\
\hline 6. Maybe. it is good that some of the groups are at the top while some are at the bottom. & 168 & 3.11 & 1.53 \\
\hline 7. Social equity should be our goal. & 168 & 4.64 & 1.45 \\
\hline 8. Sometimes, some groups should stay still. & 168 & 3.77 & 1.60 \\
\hline 9. It would be good if every group were equal. & 168 & 4.05 & 1.61 \\
\hline 10. Equity of the groups should be our goal. & 168 & 4.31 & 1.47 \\
\hline 11. To reach goal of your group, sometimes, it is needed to use power against other groups. & 168 & 3.15 & 1.62 \\
\hline 12. We need to do whatever we can do in order to enable equity in terms of other groups' conditions. & 168 & 4.15 & 1.59 \\
\hline 13. Inferior groups should stay still. & 168 & 2.67 & 1.68 \\
\hline 14. If we had treated other groups differently, we would have fewer problems. & 168 & 4.06 & 1.62 \\
\hline 15. In order to make incomes more equal, we need to do whatever we can do. & 168 & 4.32 & 1.44 \\
\hline 16. In order to progress in life, sometimes, we need to suppress other groups. & 168 & 2.95 & 1.82 \\
\hline Mean & & 3.73 & 1.61 \\
\hline
\end{tabular}

Table 2. Degree of students' self-esteem at decision-making delay.

\begin{tabular}{|c|c|c|c|}
\hline & $\mathrm{N}$ & Mean & SD \\
\hline 1. I trust my decision-making ability & 168 & 2.75 & 0.45 \\
\hline 2. When I make a decision. I see myself as inferior. & 168 & 2.52 & 0.73 \\
\hline 3. I think I am successful at decision-making. & 168 & 2.54 & 0.65 \\
\hline 4. I feel myself so in despair that I give up making effort for decision-making. & 168 & 2.51 & 0.75 \\
\hline 5. The decisions that I made ends up good. & 168 & 2.40 & 0.60 \\
\hline 6. It is easy to persuade me that other people's decisions are accurate rather than my decisions. & 168 & 2.38 & 0.75 \\
\hline Mean & & 2.52 & 0.65 \\
\hline
\end{tabular}


Table 3. Comparison of students' individual perception of a just world, degree of self-esteem at decision making and decision-making styles according to level of doing sports.

\begin{tabular}{llcccc}
\hline Variables & & $\begin{array}{c}\text { Sum of the } \\
\text { Squares }\end{array}$ & $\begin{array}{c}\text { Mean of the } \\
\text { Squares }\end{array}$ & $\mathrm{F}$ & $\mathrm{P}$ \\
\hline & & & & & \\
Perception of a just world & Among the level of sport & 2.278 & 0.759 & 1.838 & 0.142 \\
Self-esteem at decision making & Among the level of sport & 1.759 & 0.586 & 4.519 & $0.004^{*}$ \\
Careful Decision-making & Among the level of sport & 1.286 & 0.429 & 2.008 & 0.115 \\
Evasive Decision-making & Among the level of sport & 2.227 & 0.742 & 2.844 & 0.059 \\
Decision-making delay & Among the level of sport & 0.728 & 0.243 & 0.916 & 0.434 \\
Panic decision-making & Among the level of sport & 0.167 & 0.056 & 0.232 & 0.874 \\
& & & & & \\
\hline
\end{tabular}

${ }^{*} \mathrm{P}<0.05$

Table 4. Comparison of self-esteem at decision making of students who participated in the study with their level of doing sports.

\begin{tabular}{|c|c|c|c|c|c|}
\hline Variables & (I) Level in sports & (J) Level in sports & $\begin{array}{l}\text { The difference between } \\
\text { means (I-J) }\end{array}$ & SD & $\mathrm{P}$ \\
\hline \multirow{12}{*}{ 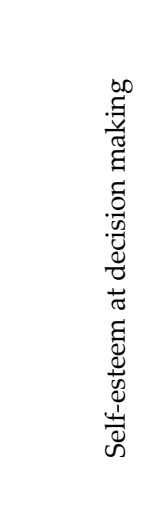 } & \multirow{3}{*}{ Amateur } & Leisure time activity & 0.084 & 0.064 & 0.557 \\
\hline & & Professional & 0.174 & 0.104 & 0.339 \\
\hline & & At the national level & -0.237 & 0.093 & 0.058 \\
\hline & \multirow{3}{*}{ Leisure time activity } & Amateur & -0.084 & 0.064 & 0.557 \\
\hline & & Professional & 0.091 & 0.109 & 0.839 \\
\hline & & At the national level & -0.321 & 0.099 & $0.008^{*}$ \\
\hline & \multirow{3}{*}{ Professional } & Amateur & -0.174 & 0.104 & 0.339 \\
\hline & & Leisure time activity & -0.091 & 0.109 & 0.839 \\
\hline & & At the national level & -0.411 & 0.128 & $0.009^{*}$ \\
\hline & \multirow{3}{*}{ At the national level } & Amateur & 0.237 & 0.093 & 0.058 \\
\hline & & Leisure time activity & 0.321 & 0.099 & $0.008^{*}$ \\
\hline & & Professional & 0.411 & 0.128 & $0.009^{*}$ \\
\hline
\end{tabular}

${ }^{*} \mathrm{P}<0.05$

Table 5. Comparison of students' individual perception of a just world, degree of self-esteem at decision making and decision-making styles according to their habitual residence.

\begin{tabular}{|c|c|c|c|c|c|}
\hline Variables & & $\begin{array}{l}\text { Sum of the } \\
\text { Squares }\end{array}$ & $\begin{array}{c}\text { Mean of the } \\
\text { Squares }\end{array}$ & $\mathrm{F}$ & $\mathrm{P}$ \\
\hline Perception of a just world & Among the habitual residence & 4.971 & 2.485 & 6.305 & $0.002^{*}$ \\
\hline Self-esteem at decision making & Among the habitual residence & 0.444 & 0.222 & 1.623 & 0.200 \\
\hline Careful Decision-making & Among the habitual residence & 0.473 & 0.236 & 1.089 & 0.339 \\
\hline Evasive Decision-making & Among the habitual residence & 0.208 & 0.104 & 0.383 & 0.683 \\
\hline Decision-making delay & Among the habitual residence & 0.097 & 0.048 & 0.181 & 0.835 \\
\hline Panic decision-making & Among the habitual residence & 0.052 & 0.026 & 0.110 & 0.896 \\
\hline
\end{tabular}

* $\mathrm{P}<0.05$

Table 6. Comparison of students' perception of a just world with their habitual residence.

\begin{tabular}{|c|c|c|c|c|c|}
\hline Variables & (I) habitual residence & (J) habitual residence & $\begin{array}{c}\text { Difference between } \\
\text { means (I-J) }\end{array}$ & SD & $\mathrm{P}$ \\
\hline \multirow{6}{*}{ 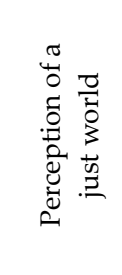 } & \multirow{2}{*}{ City center } & County town & 0.283 & 0.148 & 0.136 \\
\hline & & Village-town & 0.546 & 0.171 & $0.005^{*}$ \\
\hline & \multirow{2}{*}{ County town } & City center & -0.283 & 0.148 & 0.136 \\
\hline & & Village-town & 0.263 & 0.212 & 0.432 \\
\hline & \multirow{2}{*}{ Village-town } & City center & -0.546 & 0.171 & $0.005^{*}$ \\
\hline & & County town & -0.263 & 0.212 & 0.432 \\
\hline
\end{tabular}


When the table 5 is examined, it seen that selfesteem at decision-making, careful decision-making, evasive decision-making, decision-making delay and panic decision-making styles do not show difference according to students' habitual residence ( $p>0.05)$. However, students' perception of a just world shows a significant difference according to habitual residence $(\mathrm{p}<0.05)$.

When the table 6 is examined, it is seen that there is a significant difference between students who live at the city center and students who live in village-town. According to that, the mean of individual perception of a just world of the students who live in city center is found significantly higher than the students' who live in village-town.

\section{DISCUSSION}

The mean of the answers to the questions about students' individual perception of just world is calculated as 3.73. Students' individual perception of a just world is quite close to 4 (neutral value). According to this, it seems that students' individual perception of a just world is at the degree of indecision. The value of the mean of the first six items that the students' degree of self-esteem is determined is 2.52 which is the degree of accurate. According to that, we can say that students' degree of self-esteem at decision-making is high. According to the study of Brown \& Mann (4), individuals who have high self-esteem are more skillful and efficient at decision-making, and also, they have more systematic and detailed thinking at decision-making process. The mean of the answers that the students gave to the questions about careful decision-making is 2.47 which is at the degree of accurate. According to that, we can say that students are mostly careful when they make decisions. . The mean of the answers that the students gave to the questions about evasive decision-making is 1.82 which is at the degree of sometimes accurate. According to that, we can say that students sometimes behave evasively when they make decisions. The mean of the answers that the students gave to the questions about decision-making delay is 1.91 which is at the degree of sometimes accurate. According to that, we can say that students sometimes delay their decision-making process. The mean of the answers that the students gave to the questions about panic decision-making is 2.05 which are at the degree of sometimes accurate. According to that we can say that students sometimes panic at their decision-making process. When we compare students' individual perception of just world, and their self-esteem at decision- making and decision-making styles in terms of their demographic features, it is seen that there is not a significant difference between the groups according to variables of gender, the grade they are in. their department they study and the dwelling place. The study of Avşaroğlu \& Üre (1) has shown that mean of the self-esteem degree and decision-making styles of the university students do not significantly differ according to gender of the students. We can say that, as the studies done by (24) and (25), some of the studies support the findings of our study that decision-making styles do not cause significant difference in terms of gender variable. It is seen that there is a significant difference only according to the variables of the level of doing sports and the habitual residence. The mean of the answers that the students gave to the questions about panic decisionmaking is 2.05 which is at the degree of sometimes accurate. According to that, we can say that students sometimes panic at their decision-making process. Furnham \& Proctor (10) state that the more groups that encounter with injustice, the less they perceive the world as just. It seen that students' perception of a just world, careful decision-making, evasive decision-making, decision-making delay and panic decision-making styles do not change according to their level of doing sports $(p>0.05)$. It is seen that there is a significant difference at the self-esteem at decision-making factor according to students' level of decision-making $(p<0.05)$. It is seen that there is a significant difference between students who do sports as a leisure time activity and as professionals and students at the national level. According to that, mean of self-esteem at decision making of the students at the national level is significantly higher than students who do sports as a leisure time activity and as professionals. It seen that self-esteem at decision-making, careful decision-making, evasive decision-making, decision-making delay and panic decision-making styles do not show difference according to students' habitual residence $(p>0.05)$. However, students' perception of a just world shows a significant difference according to habitual residence $(p<0.5)$. There is a significant difference between students who live at the city center and students who live in village-town. According to that, the mean of individual perception of a just world of the students who live in city center is found significantly higher than the students' who live in village-town. As the result of the correlation analysis that are done to determine whether there is a significant relationship between students' individual perception of a just world with selfesteem at decision-making and decision-making 
styles or not, it is seen that there is no significant relationship in terms of all aspects between students' individual perception of a just world with self-esteem at decision-making and decision-making styles. In conclusion, there is not a significant relationship between the degree individual perception of a just world of the students who participated in the study and their opinion about decision-making.

\section{REFERENCES}

1. Avşaroğlu S, Üre O. Üniversite Oğrencilerinin Karar Vermede Özsaygi. Karar Verme ve Stresle Basacıkma Stillerinin Benlik Saygısı ve Bazı Degişkenler Açısından Incelenmesi. Selçuk University J Institute of Social Sciences, 2007; 18: 85-100.

2. Bağırkan Ş. Karar Verme. İstanbul: Der Yayınları.1983.

3. Borg WR. Educational Research New York: David McKay Co. Catherine Soanes. Oxford English Dictionary. Oxford University Press. 2007. New Delhi. P. 22, 1985.

4. Brown EJ, Mann L. The relationship between family structure and process variables and adolescent decision-making. Journal of Adolescence, 1991; 13: 25-37.

5. Can H. Organizasyon ve Yönetim (7. Bask1). Siyasal Kitabevi, Ankara, 2005

6. Carney C, Wells C. Discover the Career Within You. New York. Cole Publishing Company, 1995.

7. Çolakkadıoğlu O. Ergenlerde Karar Verme Ölçeği'nin (Adolescent Decision Making Questionnaire) uyarlama çalışması. Master Thesis, Çukurova University, Adana, 2003.

8. Dalbert C. The world is more just for me than generally: About the personal belief in a just world scale's validity. Social Justice Research, 1999; 12: 79-98.

9. Deniz ME. Investigation of the relation between decision making self- esteem. Decision making style and problem solving skills of university students. Eurasian Journal of Educational Research, 2004; 15: 23-35.

10. Furnham A, Proctor E. Belief in the just world: review and critique of the individual differences literature. British Journal of Social Psychology, 1989; 28: 365-384.

11. Güçray SS. Bazı Kişisel Değişkenler Algılanan Sosyal Destek ve Atılganlııın Karar Verme Stilleri İle İliskisi. Psikolojik Danısma ve Rehberlik Dergisi, 1998; 2(9): 7-16.
12. Goldberg JH, Lerner JS, Tetlock PE. Rage and reason: The psychology of the intuitive prosecutor. European Journal of Social Psychology, 1999; 29: 781-795.

13. Göregenli M. Siddet, kotu muamele ve iskenceye iliskin degerlendirmeler, tutumlar ve deneyimler. Iskencenin Onlenmesinde Hukukcuların Rolu Projesi Raporu. Izmir, 2003.

14. Hafer CL, Bègue L. Experimental research on just-world theory: Problems. developments. and future challenges. Psychological Bulletin, 2005; 131: 128-167.

15. Koçel T. İşletme Yöneticiliği. İstanbul, Beta Basım, 2001.

16. Kuzgun Y. Karar stratejileri ölçeği: geliştirilmesi ve standardizasyonu. VII. Ulusal Psikoloji Kongresi Bilimsel Çalışmaları. 161-170. Ankara, 1992.

17. Lerner MJ. The Belief in a Just World: A Fundamental Delusion. New York: Plenum Press, 1980.

18. Lerner MJ. Pursuing the justice motive. M. Ross and Date T. Miller Eds. In: The justice motive in everyday life. New York: Cambridge University, Press, 2002.

19. Lipkus IM, Siegler IC. The belief in a just world and perceptions and discrimination. J of Psychology, 1993; 127: $465-474$.

20. Mann L, Radford M, Burnett P, Ford S, Bond M, Leung K, Nakamura H, Vaughan G, Yang KS. Cross-Cultural Differences in Self-Reported Decision- Making Style and Confidence. International Journal of Psychology, 1998; 33: 325-335.

21. Mitchell LK, Krumboltz YD. Research on human decision making: Implications for career decision making and counseling. In R. W. Lent. \& S. D. Brown (Eds). Handbook of Counseling Psychology. A Wiley- Interscience Publication, USA, 1984

22. Otto K, Dalbert C. Belief in a Just world and its function for young prisoners. Journal of Research in Personality, 2005; 39: 559-573.

23. Pepitone A, L"Armand, K. The justice and injustice of life events. European Journal of Social Psychology, 26. 581597.1996

24. Sinangil K.H. Yonetici Adaylarında Karar Verme İle Kaygı İliskileri. VII. Ulusal Psikoloji Kongresi Bilimsel Çalışmaları. Ankara: Turk Psikologlar Dernegi Yayınları, 1993.

25. Tasdelen A. Öğretmen Adaylarının Farklı Psiko Sosyal Değiskenlere Göre Karar Verme Stilleri. Doctoral Thesis, Institute of Education Sciences, Dokuz Eylul University, Izmir, 2002. 